\title{
Characterization of new sources of derivative starches as wall materials of essential oil by spray drying
} Iñigo VERDALET-GUZMÁN ${ }^{1}$, Laura MARTÍNEZ-ORTIZ1 ${ }^{1}$, Fernando MARTÍNEZ-BUSTOS²*

\begin{abstract}
Starch derivatives of taro (Colocasia esculenta L. Schott) and rice were characterized as wall materials of orange oil ( $d$-limonene) by spray drying. Native starches were initially hydrolyzed with $\mathrm{HCl}$ and then esterified. Succinylated starches were modified using a conventional method in a slurry and were extruded; whereas, the phosphorylated starches were modified using the extrusion process. Viscosity and solubility of starches reduced after acid hydrolysis, derivatization, and extrusion. The particle size of the wall materials ranged between 20.05 and $31.81 \mu \mathrm{m}$. The encapsulation efficiency of the phosphorylated taro, rice, and waxy corn starches was 96.9, 96.8 and $97.1 \%$ respectively, and 98.6, 98.1, and 98.8\% for succynilated taro, rice, and waxy corn starches, respectively. Starch derivatives of taro and rice could potentially be used as wall materials of orange oil $d$-limonene.
\end{abstract}

Keywords: taro; rice; starch derivatives; wall materials.

\section{Introduction}

Food industry has focused on discovering and evaluating new wall materials for flavor encapsulation by spray drying considering their functionality as encapsulating agents, cost, authorized grade, and accessibility. Carbohydrates, mainly sugars such as glucose and sucrose, along with polysaccharides such as starch, maltodextrins, pectin, alginate, and chitosan are successfully used as wall materials for encapsulation of flavor ingredients (KENYON, 1995). However, carbohydrates cannot be used in wall systems without the presence of a surfaceactive constituent because they usually have no emulsifying properties (BANGS; REINECCIUS, 1988). Hydrolyzed starch products are hydrophilic compounds, which have little affinity for hydrophobic flavors (SHAIKH; BHOSALE; SINGHAL, 2006). Their hydrophilic nature can be modified by linking hydrophobic side chains (DRUSCH; SCHWARZ, 2006). Extrusion processes have unique characteristics compared to other thermal processes. Extrusion processes break covalent bonds in polymers, create intense structural disruption, mix and facilitate reactions in the absence of effluents that in other processes are limited or are made available to a lesser extent (ASP; BJÖRK, 1989). Extrusion may use reduced amounts of reagents; moreover, further hydrolysis of desirable starch for microencapsulation purposes can occur. Native rice starches consist of tiny granules $(5 \mathrm{~mm}$ ) with narrow size distribution (PUCHONGKAVARIN; VARAVINIT; BERGTHALLER, 2005). Taro starch granules have irregular and polygonal shapes with an average size of $3.0 \mu \mathrm{m}$ (JANE et al., 1992); these granules exhibit the capability to form spherical aggregates. Small starch granules used as wall materials can be combined into porous spheres when dried by aspersion, and they have a wide range of useful applications. Thus, the aim of this study was to analyze the potential of taro and rice starch derivatives to be used as wall material of orange oil by spray drying.

\section{Materials and methods}

\subsection{Raw materials}

Fresh taro tubers were donated by producers from Papaloapan, Veracruz, México. Commercial "Valle Verde" rice flour was purchased from a local market. Waxy maize starch was acquired from National Starch, México. Sodium tripolyphosphate (Sigma-Aldrich, Toluca de Lerdo, México) and $\eta$-octenyl succinic anhydride (Sigma-Aldrich, Toluca de Lerdo, México) were used to prepare the modified starches. Orange oil (d-limonene) was donated by Food Specialities, México.

\subsection{Extraction of starch and starch hydrolysis}

Taro starch was extracted from fresh tubers (PEREIRA PACHECO; MOLINA MEDINA, 1992). Rice starch was extracted from rice flour with $\mathrm{NaOH}$. Before esterification, both starches were hydrolyzed using $3.4 \mathrm{~g}$ of pure $\mathrm{HCl} / 100 \mathrm{~g}$ of starch (d.b.); hydrolysis was carried out in a water bath at $50^{\circ} \mathrm{C}$ for 6 hours (ZAMBRANO; CAMARGO, 2001).

\subsection{Dextrose Equivalent (DE)}

DE was determined by the phenol-sulfuric acid method (DUBOIS et al., 1956).

\subsection{Phosphorylated and succynilated starches preparation}

Starch phosphorylation was achieved following the Chang and Lii (1992) method using a single screw extruder designed and manufactured by CINVESTAV-IPN. The extrusion process was done at 70,125 and $180{ }^{\circ} \mathrm{C}$, feeding, transition, and high pressure zones respectively. Screw speed was $25 \mathrm{rpm}$ with a $70 \mathrm{~g} / \mathrm{min}$ feed rate, $3: 1$ compression ratio, and $2.9 \mathrm{~mm}$ diameter

${ }^{1}$ Instituto de Ciencias Básicas, Universidad Veracruzana - UV, Av. Dr. Rafael Sánchez Altamirano, s/n, Col. Industrial-Animas, C.P. 91190, Xalapa, VER, México

${ }^{2}$ Centro de Investigación y de Estudios Avanzados del Instituto Politécnico Nacional - CINVESTAV, Unidad Querétaro, Libramiento Norponiente \#2000,

Fracc. Real de Juriquilla, C.P. 76230, Santiago de Querétaro, QRO, México, e-mail: fmartinez@qro.cinvestav.mx

${ }^{*}$ Corresponding author 
die nozzle. The extruded products were dried for 24 hours in a convection oven at $45{ }^{\circ} \mathrm{C}$ and milled in a Braun coffee mill. They were then passed through a 100 mesh sieve $(149 \mu \mathrm{m})$ and stored in polyethylene bags at $4{ }^{\circ} \mathrm{C}$ for further analysis. Starch succinylation was performed with $\eta$-octenyl succinic anhydride, according to the Jeon, Viswanathan and Gross (1999) method. The dried powder was stored in polyethylene bags at $4{ }^{\circ} \mathrm{C}$. After esterification, $\eta$-OSA starches were further extruded in a single screw extruder, under the same conditions used for starch phosphorylation. Waxy maize starch, used as control, was also modified under the same conditions used for taro and rice starches.

\subsection{Analysis of modified starches}

Substitution degree of phosphorylate and succinylate starches

Degree of phosphorus substitution (DS) was calculated following the method of Chang and Lii (1992).

The substitution degree of succinate was obtained following the method of alkenyl-succinates (JEON; VISWANATHAN; GROSS, 1999). Degree of substitution was calculated according to Song et al. (2006).

\subsection{Water absorption index (WAI) and Water solubility index (WSI) of starches}

WAI and WSI were registered following the method of Anderson et al. (1969). Three repetitions were performed for each analysis, from which the mean value was reported.

\subsection{Pasting properties of starches}

The pasting properties of starches were measured in a 3C Rapid Visco Analyzer (RVA, Newport Scientific PTY LTD, Sydney Australia). The analysis was based on the AACC standard program for RVA analysis with some modifications (AMERICAN..., 1999).

\subsection{Microencapsulation}

Microcapsules were prepared by Spray Drying (SD-Basic Spray-Dryer, LabPlant, Huddersfield, UK). Emulsions of $30 \mathrm{~g}$ (d.b.) were prepared dispersing $20 \mathrm{~g}$ of wall material in $100 \mathrm{~mL}$ of deionized water at room temperature.

Emulsions were homogenized at $14,000 \mathrm{rpm} \times \mathrm{g}$ for 4 minutes (Ultra Turrax T-25-SI, IKA Works, USA). Drying conditions were: inlet air temperature at $180 \pm 1{ }^{\circ} \mathrm{C}$, outlet air temperature of $100 \pm 5^{\circ} \mathrm{C}, 0.5 \mathrm{~mm}$ nozzle diameter, liquid flow rate of $7.5 \mathrm{~mL} / \mathrm{min}$, and fixed equipment air flow (approximately $\left.70 \mathrm{~m}^{3} / \mathrm{h}\right)$.

\subsection{Emulsions particle size}

The particle size analysis of the emulsions of modified starches with d-limonene was carried out by laser diffraction (model Beckman Coulter LS).

\subsection{Apparent viscosity of the emulsions}

Rheological measurements were performed with $8 \mathrm{ml}$ of the emulsion (4:1 oil:starch) at $25^{\circ} \mathrm{C}$ controlled temperature using a digital rotational Brookfield Viscometer (Model RVT, Brookfield Engineering Laboratories, Stoughton, MA) (SOPADE; FILIBUS, 1995).

\subsection{Microcapsules characterization}

Morphology and particle size of the microcapsules were measured using scanning electronic microscopy (ESEM EDDAX, GSE detector), at an acceleration voltage of $20 \mathrm{kV}$. The encapsulated samples were fixed in stubs containing a doublefaced adhesive metallic tape.

\subsection{Yield and efficiency of encapsulation}

These parameters were calculated from determinations of non-encapsulated surface $d$-limonene content and the total oil of the microcapsules. The non-encapsulated surface $d$-limonene from the powdered samples was extracted using the Soxhlet extraction method, following Beristain and VernonCarter (1994) method. The total oil in the microcapsules was determined using a Clevenger apparatus.

\subsection{Water activity $\left(a_{w}\right)$}

Water activity $\left(a_{w}\right)$ was measured using an Aqua Lab equipment (ASSOCIATION..., 1990).

\subsection{Moisture content of the microcapsules}

The moisture content of the microcapsules was determined gravimetrically by oven-drying at $100^{\circ} \mathrm{C}$ over a 24 hours period.

\subsection{Statistical analysis}

All experiments were performed in triplicate and assessed by analysis of variance (STATSOFT, 2001) The data were calculated using the STATISTICA (Analysis of variance) and the Tukey's test $(\mathrm{p}<0.05)$, Software package version 6.0 (STATSOFT, 2001).

\section{Results and discussion}

\subsection{Characterization of modified starches}

Dextrose equivalent (DE). DE values after hydrolysis of starches with $\mathrm{HCl}$ (3.5\%) for 6 hours were 4.5, 4.8, and 5.8 for taro, rice, and waxy maize, respectively.

\section{Degree of substitution (DS)}

The highest values of phosphorus content and DS of phosphorylated starches were found for rice, and the lowest one was found for taro starch (Table 1). These values corroborate the data found by Moorthy (2002), who reported phosphorus content between 0.006 and 0.013 in native taro starch. MurúaPagola, Beristain-Guevara and Martinez-Bustos (2009); Chang and Lii (1992) reported higher phosphorous values for waxy 
and normal corn starches than those here reported. For all the $\eta$-octenylsuccinylated ( $\eta$-OSA) starches, the DS values were 0.07. Song et al. (2006) found a similar DS value for Early Indica rice starch using OSA concentrations higher than 15\%. These values were lower than those found in the present research.

Jeon, Viswanathan and Gross (1999) found a DS of 0.11 in modified OSA waxy corn starch, having performed the esterification in similar conditions to those described in the present research, $60 \%$ starch slurry ( $\mathrm{w} / \mathrm{w}$ relative to water), and a concentration higher than $15 \%$ OSA (w/w relative to starch).

Bhosale and Singhal (2006) reported a linear increase in the DS of the OSA-modified amaranth and waxy corn starches with an increase in concentration of OSA. The amount of 3\% OSA provided maximum DS to both modified OSA-amaranth and OSA-waxy corn starch under similar reaction conditions.

\section{Pasting properties of starches}

Table 2 shows the maximum viscosity during heating cycle, the water absorption index, and the water solubility index of native and hydrolyzed starches. Hydrolyzed starches considerably lowered its maximum viscosity compared to that of native starches. Taro starch was the most affected by hydrolysis, followed by waxy corn starch and finally rice starch. The maximum phosphorylated starches viscosity values were $18.94,18.72$, and 18.47 for taro, rice, and waxy corn, respectively, whereas, succynilated taro, rice and waxy corn starches showed values of $18.76,15.35$, and 11.37 respectively. This is attributable to the fact it occurs during the hydrolysis and extrusion process, in which the structure of starch is depolymerized by shearing, high pressure, and temperature (CHANG; LII, 1992). Un-depolymerized starches are rarely used for spray drying because of their high viscosity. Extruded starches usually show lower viscosity profile compared with

Table 1. Phosphorous content and degree of substitution of phosphorylated and succynilated starches.

\begin{tabular}{cccc}
\hline Starch & $\begin{array}{c}\text { Phosphorus } \\
\text { content (\%) }\end{array}$ & DS $_{\text {PHOS }}$ & DS $_{\text {OSA }}$ \\
\hline Taro & 0.575 & 0.031 & 0.07 \\
Rice & 0.746 & 0.040 & 0.07 \\
Waxy maize & 0.732 & 0.039 & 0.07 \\
\hline
\end{tabular}

DS: Degree substitution; OSA: octenyl succinate anhydride.

Table 2. Maximum viscosity, water absorption index (WAI), and water solubility index (WSI) of native and hydrolyzed starches.

\begin{tabular}{cccc}
\hline Starch & MV & WAI & WSI \\
\hline Native taro & 4000 & 5.0 & 8.0 \\
Hydrolyzed taro & 12 & 1.3 & 10.5 \\
Native rice & 2750 & 4.1 & 7.8 \\
Hydrolyzed rice & 32 & 1.6 & 14.9 \\
Waxy corn & 3350 & 3.0 & 1.9 \\
Hydrolyzed Waxy corn & 20 & 0.95 & 11.1 \\
\hline
\end{tabular}

MV: maximum viscosity during the heating cycle; WAI: Water absorption index; WSI: water solubility index. All results are mean of three determinations. native starches. Hydrolyzed starches had lower WAI values than those of its native starches. Acid hydrolysis resulted in low molecular weight products that showed reduced water absorption.

Waxy corn starch showed the highest difference in WSI as an effect of the acid. The WAI values of phosphorylated starches were $1.7,2.3$, and 1.5 for taro, rice, and waxy corn, respectively. Succynilated taro, rice, and waxy corn starches had values of $0.86,1.3$, and 1.0 , respectively. The addition of hydrophobic groups to the starch molecules and cross linking formation decreased the WAI. Murúa-Pagola, Beristain-Guevara and Martinez-Bustos (2009) reported WAI values from 2.22 to 4.09 for phosphorylated, acetylated, and succynilated waxy maize starches. Changes in the WAI as a result of the studied variables could be due to the effects of acid. In addition, the extrusion of starch granules would open their structures which would then result in high water retention.

\subsection{Characterization of emulsions}

\section{Apparent viscosity of the emulsions}

The microstructure of spray dried microcapsules can be affected by the composition and properties of wall materials, its drying parameters, and the emulsion viscosity, which in consequence result in resistance to flow and prolonged storage conditions (BHOSALE; SINGHAL, 2006).

Viscosity of the modified taro starches was higher than those of the other two derivative starches. The highest viscosity was reported for succynilated taro starch, and the lowest values for succinylated rice starch. Nevertheless, fine emulsions from the powders were also obtained in all the modified starches (Table 3 ). This could be explained by the differences in the stability of emulsions during spray drying process. Bhandari et al. (1992) reported a direct relationship between the viscosity of liquid emulsions prior to spray drying and the moisture content of the powder. In addition, particle structure and porosity are additional parameters that influence their water-holding properties during drying and the evaporative rate, and inlet and outlet air temperature differentials (REINECCIUS, 2004).

\section{Particle size of the emulsions}

Table 3 shows the particle size of emulsions prepared with starch derivatives. Particle size of the modified starches was equal or lower than $9.0 \mu \mathrm{m}$, which allowed a successful step of the emulsions through the nozzle of the spray dryer. Succynilated taro and rice starches showed the highest particle size values of the evaluated emulsions, whereas, phosphorylated taro and rice starches, and succinylated waxy corn were the lowest. Sheu and Rosenberg (1995) suggested that retention of volatiles during microencapsulation by spray drying could be enhanced by reducing the mean emulsion size of the dispersed core material during emulsification. According to Jafari et al. (2008), the higher surface oil in the particles produced from 
Table 3. Viscosity and particle size of emulsions, particle size, and water activity of microcapsules.

\begin{tabular}{lccccc}
\hline \multicolumn{1}{c}{ Starch } & $\begin{array}{c}\text { Viscosity of the } \\
\text { emulsions }(\mu \mathrm{m})\end{array}$ & $\begin{array}{c}\text { Particle size of } \\
\text { emulsions }(\mu \mathrm{m})\end{array}$ & $\begin{array}{c}\text { Particle size of } \\
\text { microcapsules with } \\
d \text {-limonene }(\mu \mathrm{m})\end{array}$ & $\begin{array}{c}\text { Water activity of } \\
\text { microcapsules }\left(\mathrm{a}_{\mathrm{w}}\right)\end{array}$ & $\begin{array}{c}\text { Moisture content of } \\
\text { microcapsules } \\
(\mathrm{g} \text { water/100g solids d.b.) }\end{array}$ \\
\hline Phosphorylated taro & 1.01 & 7.7 & $21.12 \pm 1.4$ & $0.187 \pm 0.049$ & $2.37 \pm 0.04$ \\
Succynilated taro & 1.336 & 8.4 & $30 \pm 1.5$ & $0.185 \pm 0.043$ & $2.27 \pm 0.06$ \\
Phosphorylated rice & 0.261 & 6.4 & $20.19 \pm 0.8$ & $0.186 \pm 0.031$ & $2.31 \pm 0.05$ \\
Succynilated rice & 0.126 & 9.0 & $29.78 \pm 0.6$ & $0.183 \pm 0.035$ & $2.30 \pm 0.04$ \\
Phosphorylated Waxy corn & 0.981 & 7.4 & $20.05 \pm 0.5$ & $0.148 \pm 0.059$ & $2.25 \pm 0.07$ \\
Succynilated Waxy corn & 0.562 & 6.5 & $31.81 \pm 1.6$ & $0.146 \pm 0.022$ & $2.30 \pm 0.03$ \\
\hline
\end{tabular}

All results are mean of three determinations measured in the powders eight days they were prepared by spray drying. Samples were kept frozen before the determination.

emulsions with larger droplets can be attributed to droplets breakdown during atomization. Moreover, lower oil content resulted in higher emulsion viscosity, which reduces oil droplets diffusion inside atomized droplets and makes oil migration to the particle surface difficult. Soottitantawat et al. (2004) reported the influence of the mean emulsion droplet size on $d$-limonene retention during spray drying; ethyl butyrate and ethyl propionate were used as model flavors. Gum Arabic, soybean water-soluble polysaccharides, or modified starch blended with maltodextrin were used as wall materials, and these authors found that the increasing emulsion droplet decreased the retention of flavors. Risch and Reineccius (1998) have also shown in a similar research that a smaller emulsion size yields a higher retention of orange oil. Soottitantawat et al. (2005) reported the influence of emulsion size on the retention during spray drying of soluble and insoluble flavor.

The smaller emulsion size showed higher retention than the large emulsion size, especially for the insoluble flavor. The distribution curve containing larger emulsion droplets shifted toward a smaller size after atomization, indicating that the larger emulsion droplets would be changed in size during atomization and result in decreasing flavor retention. Paramita, Furuta and Yoshii (2012) used modified starch (wall material) by spray drying to produce oil-rich powders of oil mixtures of medium-chain triglycerides (MCT) and $d$-limonene in mixing ratios from 10 to $100 \mathrm{wt} \%$. The viscosity of the infeed liquid and the particle size of the powder exponentially decreased with increasing oil load, while the emulsion droplet size in the infeed liquid increased. In addition, retention of $d$-limonene during spray drying also decreased markedly with increasing oil load, irrespective of the different oil loads. For diverse combinations of carbohydrate carrier solids, the increasing emulsion diameter resulted in a decreasing retention of $d$-limonene. This implies that a fine emulsion is stable during atomization and spray drying, and indicates that, for the proper wall materials, the emulsion droplet size is a significant factor for flavor retention (AGHBASHLO et al., 2012). Risch and Reineccius (1988) also reported in a similar research that a smaller emulsion size yields a higher retention of orange oil. As for the effect of the emulsion size on the shelf life of encapsulated orange oil flavor and encapsulated fatty acid, a longer shelf life of larger feed emulsion size was showed.

\subsection{Characterization of the microcapsules}

\section{Particle size of the microcapsules}

The size of microcapsules is dependent on physical factors such as the rate of shear, the phase viscosity, and the concentration of stabilizers, as well as, the design of the stirrer and vessel (HONG; PARK, 1999). The materials showed a similar bimodal particle distribution (data not shown). Table 3 shows that the particle size of the materials varied from 20.05 to $31.81 \mu \mathrm{m}$ in accordance with the results reported in the literature for capsules produced by spray drying (THIES, 1995). Drusch and Schwarz (2006) reported the microencapsulation of a fish oil rich in long-chain polyunsaturated fatty acids with two different types of $\eta$-octenylsuccinate-derivative starch. The particle size expressed as 50th percentile of the particle distribution ranged from 22 to $29 \mu \mathrm{m}$. Particle size was significantly affected by the composition of the emulsion and drying conditions. Data indicate that microcapsules size decreased with a decrease in oil and starch content, whereas an increase in the drying air inlet and outlet temperature led to an increase in particle size (MINEMOTO et al., 2002). Emulsified linoleic acid encapsulated with gum Arabic was smaller in droplet size and more stable than those prepared with maltodextrins, and it was also more resistant to oxidation than that in a maltodextrinbased microcapsule. Higher inlet air temperature leads to the production of larger particles and causes increasing swelling (TONON; FREITAS; HUBINGER, 2011).

\section{Water activity $\left(a_{w}\right)$ of the microcapsules}

Water activity $\left(a_{\mathrm{w}}\right)$ is an important index for spray-dried powder because it can significantly affect the food safety stability and, simultaneously with temperature, can control the physicochemical properties, along with shelf life of the fabricated microcapsules. There were no significant changes in the water activities of the spray-dried microcapsules for all the investigated derivate starches (Table 3). The highest values were found for modified taro and rice starches, and the lowest values were found for modified waxy corn starch. Pitalua et al. (2010) reported that in dry atmospheres, the water is strongly attracted to the polar sites on the surface of the microcapsules and is, therefore, not available for any type of reaction. These authors reported that low and intermediate values of degradation were found with 
beetroot juice using gum Arabic as wall material, with water activity below $0.521\left(a_{\mathrm{w}}<0.521\right)$. On other hand, when water activity values are high $\left(a_{\mathrm{w}}>0.748\right)$, the adsorption phenomenon produces conformational swelling and changes in the structure of the dry powder (SERRIS; BILIADERIS, 2001). Drusch and Schwarz (2006) found that the $a_{\mathrm{w}}$ in microcapsules of fish oil with two different types of $\eta$-octenylsuccinate-derivative starch ranged from 0.097 to 0.273 . This parameter indicates that spraydrying resulted in a stable product in terms of microbiological and physicochemical alterations during storage. An $a_{\mathrm{w}}$ value of less than 0.300 is generally considered to ensure product stability. Moisture content depends on the wall material; it is known that when wall material reaches moisture content $<7 \%$, the diffusion coefficient of water is reduced, and this decreases its movement through the dry matrix (BHANDARI et al., 1992). The moisture content of the microcapsules ranged from 2.25 to $2.37 \mathrm{~g}$ water $/ 100 \mathrm{~g}$ solids d.b. (Table 3 ). Carrillo-Navas et al. (2011) reported moisture content values from 4.82 to $5.51 \%$ in microcapsules of gum Arabic-mesquite and gum-maltodextrin. Beristain, Azuara and Vernon-Carter (2002) reported 4.91\% moisture content in microcapsules of orange peel with mesquite gum solutions as wall materials using spray drying.

\section{External morphology of the microcapsules}

Microstructures of spray-dried microcapsules have been shown to be affected by wall composition and properties, core-to-wall ratio, drying parameters, and storage conditions (SANKARIKUTTY et al., 1988). Microcapsules of the modified starches showed similar external morphologies with a smooth surface without granulate in the form of irregular spheres, although free of pores and cracks (Figure 1). Encapsulated orange oil with several commercial food proteins and gum Arabic showed that the structural morphology of the microcapsules exhibited slightly rough surfaces with cavities or dented surfaces; probably due to rapid shrinkage of the liquid droplets during the early stages of the drying process. The inner structure of the open capsules was found without any deliberate fracturing. There were slight agglomerations among individual spray dried particles (KIM; MORR, 1996). This type of capsules has been reported by Soottitantawat et al. (2005) in encapsulated $d$-limonene with mixtures of commercial waxy corn and maltodextrins.

\subsection{Encapsulation characteristics of orange oil during spray drying}

\section{Retention of orange peel oil during spray drying}

In general, modified starches had good flavor retention (Table 4). Succynylated waxy maize starch showed the best results in terms of total oil retention (86.06\%). The efficiency of inner oil retention ranged from $96.8 \%$ to $98.8 \%$ for all wall materials evaluated. These values are similar to those reported for microencapsulated lime essential oil with gum Arabic and maltodextrin (99\%) (BRINGAS-LANTIGUA; VALDÉS; PINO, 2012), and mandarin microencapsulated essential oil (KIM; MORR, 1996), and are highly related to microencapsulated orange essential oil (BRINGAS-LANTIGUA et al., 2011), which range between $72.7 \%, 85.7 \%$ and $82-100 \%$ for microencapsulated limonene (SOOTTITANTAWAT et al., 2005; MURÚA-PAGOLA; BERISTAIN-GUEVARA; MARTINEZBUSTOS, 2009).

Boutboul et al. (2002) reported that the aroma retention was increased with the specific area of starch materials. For microencapsulation by spray-drying, low viscosity of the $n$-OSA starch is desirable, with and high total solids concentration of the feed emulsion and prevention of excessive air inclusion in the microcapsules during spray drying.

On other hand, the molecular weight must not be too low since the film-formation property of starches is a prerequisite for coating and entrapping active substances by forming microcapsules. Qi and Xu (1999) reported that starch hydrolysis products have a hydrophilic nature, thus having little affinity for hydrophobic flavor oils. All evaluated modified starches showed inner oil retention higher than 96\%. Murúa-Pagola, Beristain-Guevara and Martinez-Bustos (2009) reported values of encapsulated d-limonene of 93.0, 91.9, and 95.6 for phosphorylated, succinylated, and N-Lok (control) waxy starches, respectively. Varavinit, Chaokasem and Shobsngob (2001) reported maximum values of total retained lemon oil of 62.53 and $55.00 \%$ for sago starch and taro stearate starch, respectively; 70.12 and $55.57 \%$ for pre-gelatinized hydrolyzed sago starch and taro stearate starch, respectively; and 59.15\% for Arabic gum. These values were lower than those found in the present research.

In phosphorylated taro starch, total oil retention was of 53.16 and $81.00 \%$ for succinylated taro starch, respectively. Phosphorylated and succinylated rice starches had 50.63

Table 4. Encapsulation profiles of orange oil using modified starches of taro, rice, and waxy maize dried by spray drying.

\begin{tabular}{cccccc}
\hline Starch & $\begin{array}{c}\text { Starting orange oil } \\
\text { g/100 g wall material }\end{array}$ & $\begin{array}{c}\text { Total oil g/100 g } \\
\text { capsules }\end{array}$ & $\begin{array}{c}\text { Surface oil } \\
\text { So \% }\end{array}$ & $\begin{array}{c}\text { Total oil retention } \\
\text { RMY \% }\end{array}$ & $\begin{array}{c}\text { Efficiency ME } \\
\text { (Inner oil retention) } \%\end{array}$ \\
\hline Phosphorylated taro & 20 & 10.63 & 1.60 & 53.16 & 96.99 \\
Succynilated taro & 20 & 16.20 & 1.10 & 81.00 & 98.64 \\
Phosphorylated rice & 20 & 10.12 & 1.58 & 50.63 & 65.81 \\
Succynilated rice & 20 & 6.58 & 1.20 & 55.69 & 96.87 \\
Phosphorylated Waxy corn & 20 & 9.281 & 1.56 & 86.06 & 97.19 \\
Succynilated Waxy corn & 20 & 8.61 & 1.02 & 98.82 \\
\hline
\end{tabular}

All results are mean of three determinations. 
Native starches

\section{Phosphorylated starch by extrusion}
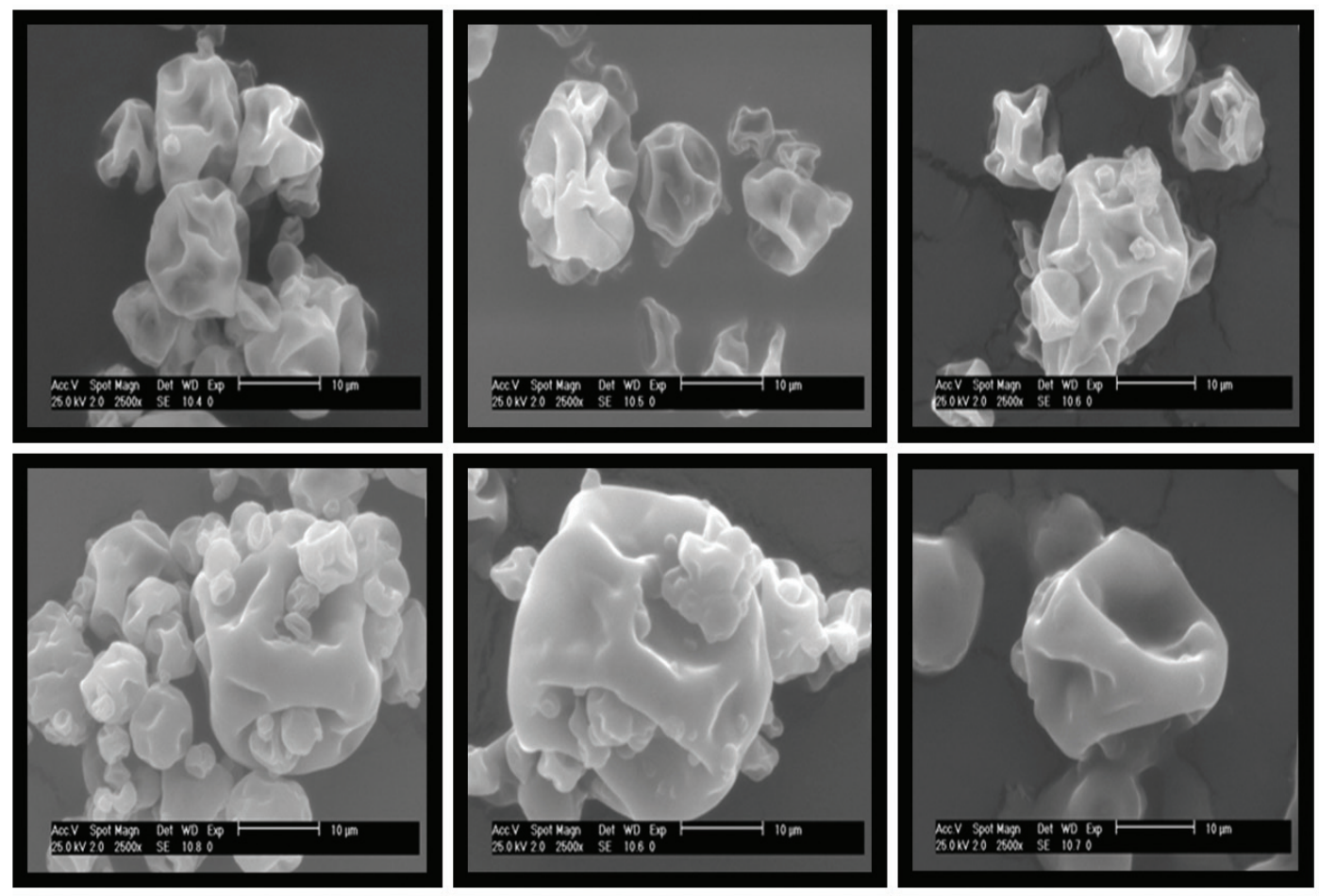

\section{Succinylated and extruded} starch

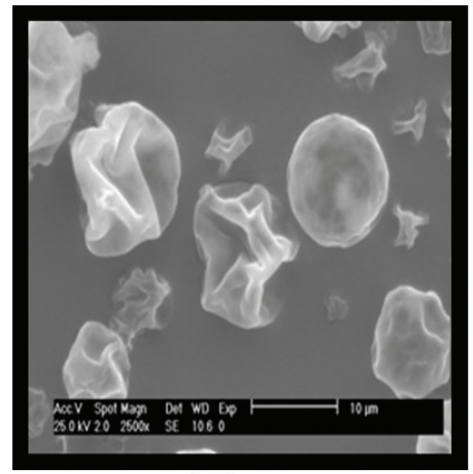

Taro

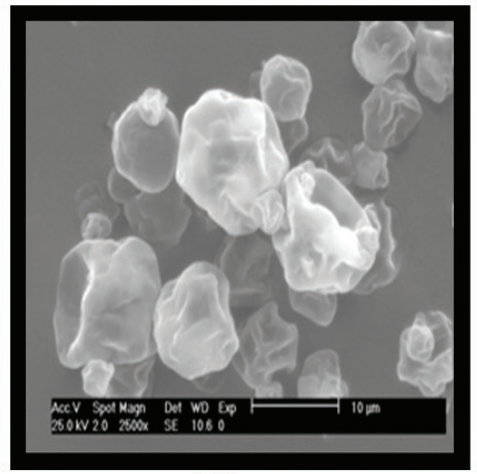

Rice

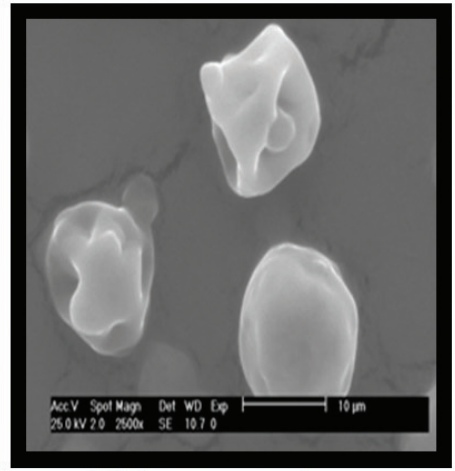

Waxy maize

Figure 1. Microphotographs of microcapsules of orange oil prepared by spray drying with taro, rice and waxy maize modified starches (2500X).

and $65.81 \%$ of total oil retention. Starch phosphates showed suitable properties as emulsion stabilizers. Starch phosphates could probably improve oil retention in blends with emulsifying starches. Surface oil contents of microencapsulated products ranged from 1.02 to $1.60 \%$ of total solids. Surface oil was higher in phosphorylated taro and rice starches than in other modified starches. Succinylated waxy corn starch had the lowest values of surface oil. The high displayed stability may be attributed to good surface-active properties (ROMÁN-GUERRERO et al., 2009) of starch derivatives which possess hydrophobic groups that are accessible in short timescale, which enable them to adhere and spread out at the interface, thereby protecting newly formed droplets from aggregating or coalescing through steric stabilization and electrostatic stabilization mechanisms (DICKINSON, 2003). According to Risch and Reineccius (1988), this parameter is strongly associated with the emulsion droplet size, and low surface oil content is very important for providing storage stability to flavorings subject to oxidative deterioration. It is desirable that a high inlet air temperature is used to allow rapid formation of a semipermeable membrane on the droplet surface, but yet not so high as to cause heat damage to the dry product or excessive bubble growth and surface disruption, which increases losses during drying or causes particles to become sticky and cake (OZMEN; LANGRISH, 2003). Huynh et al. (2008) reported that encapsulation of lemon myrtle oil, in which the outlet air temperature of the spray dryer had little effect on oil retention, surface oil significantly increased with increasing outlet air temperature. However, Bringas-Lantigua et al. (2011) reported that an inlet air temperature of $220^{\circ} \mathrm{C}$ and an outlet air temperature of $85^{\circ} \mathrm{C}$ were optimal for the spray drying of lime essential oil. Drusch and Schwarz (2006) reported that moderate spraydrying conditions (air inlet temperature of $160{ }^{\circ} \mathrm{C}$ and outlet air temperature of $60^{\circ} \mathrm{C}$ ) were advantageous since ballooning of particles and lipid oxidation during spray drying were limited compared to drying at high spray-drying temperatures. In the 
present study, inlet air temperature of $180 \pm 1{ }^{\circ} \mathrm{C}$ and outlet air temperature of $100 \pm 5{ }^{\circ} \mathrm{C}$ resulted in high efficiency of $d$-limonene retention in all the wall materials evaluated. Flavor retention of $d$-limonene by spray drying with various kinds of matrices (gum Arabic, maltodextrin, and modified starch) systems was higher than $80 \%$ (SOOTTITANTAWAT et al., 2005). According to Soottitantawat et al. (2003), the highest retention of an encapsulated moderately soluble flavor can be obtained at the optimal value of the mean emulsion droplet size.

Lee et al. (2008) found that the distribution of emulsion size in the powder showed increased fraction of large emulsion droplets and changed to a bimodal distribution. However, the modified starch HI-CAP 100 showed higher stability of encapsulated $d$-limonene than the modified potato starch. Kanakdande, Bhosale and Singhal (2007) reported that in general gum Arabic offered greater protection than maltodextrin and modified starch although the order of protection offered was volatiles $>$ cuminaldehyde $>p$-cymene $>\gamma$-terpinene.

\section{Conclusions}

The extrusion process improved the hydrolysis of starch producing wall materials with enhanced characteristics, such as solubility and viscosity, to be used in spray-drying. Derivative starches showed good viscosity, and water absorption index and water solubility index..

In addition, particle size and viscosity of the emulsions were suitable to produce microcapsules by spray drying. Oil retention and surface oil contents were satisfactory for all wall materials evaluated. The proposed materials are a low cost technological innovation with good encapsulating capabilities.

\section{References}

AGHBASHLO, M. et al. The correlation of wall material composition with flow characteristics and encapsulation behavior of fish oil emulsion. Food Research International, v. 49, n. 1, p. 379-388, 2012. http://dx.doi.org/10.1016/j.foodres.2012.07.031

AMERICAN ASSOCIATION OF CEREAL CHEMISTS - AACC. Methods of the AACC. 3rd ed. St. Paul: Academic Press Inc., 1999.

ANDERSON, R. A. et al. Gelatinization of corn grits by roll and extrusion-cooking. Cereal Science Today, v. 14, n. 4, p. 4-12, 1969.

ASP, N.G.; BJÖRK, I. Nutritional properties of extruded foods. In: MERCIER, C.; LINKO, C. P.; HARPER, J. M. (Ed.). Extrusion cooking. St. Paul: American Association of Cereal Chemists, 1989. p. 399-434.

ASSOCIATION OF OFFICIAL ANALYTICAL CHEMISTS - AOAC. Official methods of analysis. 15th ed. Arlington: AOAC International, 1990.

BANGS, W. E.; REINECCIUS, G. A. Corn starch derivatives: possible wall materials for spray-dried flavor manufacture. In: RISCH, S. J.; REINECCIUS, G. A. (Ed.). Flavour Encapsulation. Washington: American Chemical Society, 1988. p. 12-28. (ACS Symposium Series, 370).

BERISTAIN, C. I.; AZUARA, E.; VERNON-CARTER, E. J. Effect of water activity on the stability to oxidation of spray-dried encapsulated orange peel oil using mesquite gum (Prosopis juliflora) as wall material. Journal of Food Science, v. 67, n. 1, p. 206-211, 2002. http://dx.doi.org/10.1111/j.1365-2621.2002.tb11385.x
BERISTAIN, C. I.; VERNON-CARTER, E. J. Utilization of mesquite (Prosopis julijlora) gum as emulsion stabilizing agent for spraydried encapsulated orange peel oil. Drying Technology, v. 12, n. 7, p. 1727-1733, 1994. http://dx.doi.org/10.1080/07373939408962195

BHANDARI, B. R. et al. Flavor encapsulation by spray drying: application to citral and linalyl acetate. Journal of Food Science, v. 57, n. 1, p. 217-221, 1992. http://dx.doi.org/10.1111/j.1365-2621.1992. tb05459.x

BHOSALE, R.; SINGHAL, R. Process optimization for the synthesis of octenyl succinyl derivative of waxy corn and amaranth starches. Carbohydrate polymers, v. 66, n. 4, p. 521-527, 2006. http://dx.doi. org/10.1016/j.carbpol.2006.04.007

BOUTBOUL, A. et al. Influence of the nature and treatment of starch on aroma retention. Carbohydrate Polymers, v. 47, n. 1, p. 73-82, 2002. http://dx.doi.org/10.1016/S0144-8617(01)00160-6

BRINGAS-LANTIGUA, M. et al. Influence of spray-dryer air temperatures on encapsulated mandarin oil. Drying Technology, v. 29 , n. 5, p. 520-526, 2011. http://dx.doi.org/10.1080/07373937. 2010.513780

BRINGAS-LANTIGUA, M.; VALDÉS, D.; PINO, J. A. Influence of spray-dryer air temperatures on encapsulated lime essential oil. International Journal of Food Science and Technology, v. 47, n. 7 , p. 1511-1517, 2012. http://dx.doi.org/10.1111/j.13652621.2012.02999.x

CARRILLO-NAVAS, H. et al. Storage stability and physicochemical properties of passion fruit juice microcapsules by spray-drying. Revista Mexicana de Ingeniería Química, v. 10, n. 3, p. 421-430, 2011.

CHANG, Y.-H.; LII, C.-Y. Preparation of starch phosphate by extrusion. Journal of Food Science, v. 57, n. 1, p. 203-205, 1992. http://dx.doi. org/10.1111/j.1365-2621.1992.tb05456.x

DICKINSON, E. Hydrocolloids at interfaces and the influence on the properties of dispersed systems. Food Hydrocolloids, v. 17, n. 1, p. 25-39, 2003. http://dx.doi.org/10.1016/S0268-005X(01)00120-5

DRUSCH, S.; SCHWARZ, K. Microencapsulation properties of two different types of n-octenylsuccinate derivative starch. European Food Research Technology, v. 222, p. 155-164, 2006. http://dx.doi. org/10.1007/s00217-005-0020-3

DUBOIS, M. et al. Colorimetric method for determination of sugars and related substances. Analytical Chemistry, v. 28, n. 3, p. 350356, 1956. http://dx.doi.org/10.1021/ac60111a017

HONG, K.; PARK, S. Preparation of polyurea microcapsules with different composition ratios: structures and thermal properties. Materials Science and Engineering, v. 272, n. 2, p. 418-421, 1999. http://dx.doi.org/10.1016/S0921-5093(99)00509-2

HUYNH, K. P. et al. Essential oil from lemongrass extracted by supercritical carbon dioxide and steam distillation. The Phillippine Agricultural Scientist, v. 91, n. 1, p. 36-41, 2008.

JAFARI, S. M. et al. Encapsulation efficiency of food flavors and oils during spray drying. Drying Technology, v. 26, n. 7, p. 816-835, 2008. http://dx.doi.org/10.1080/07373930802135972

JANE, J. et al. Physical and chemical studies of taro starches and flours. Cereal Chemistry, v. 69, p. 528-535, 1992.

JEON, Y. S.; VISWANATHAN, A.; GROSS, R. A. Studies of starch esterification: Reactions with alkenyl-succinates in aqueous slurry systems. Starch/Stärke, v. 51, n. 2-3, p. 90-93, 1999. http:// dx.doi.org/10.1002/(SICI)1521-379X(199903)51:2<90::AIDSTAR90>3.0.CO;2-M

KANAKDANDE, D.; BHOSALE, R.; SINGHAL, R. S. Stability of cumin oleoresin microencapsulated in different combination of gum arabic, 
maltodextrin and modified starch. Carbohydrate Polymers, v. 67, n. 4, p. 536-541, 2007.

KENYON, M. M. Modified starch, maltodextrin, and corn syrup solids as wall materials for food encapsulation. In: RISCH, S. J.; REINECCIUS, G. A. (Ed.). Encapsulation and controlled release of food ingredients. Washington: American Chemical Society, 1995. p. 42-50. (ACS Symposium Series).

KIM, Y. D.; MORR, C. V. Microencapsulation properties of gum Arabic and several food proteins: spray-dried orange oil emulsion particles. Journal of Agricultural and Food Chemistry, v. 44, n. 5, p. 13141320, 1996. http://dx.doi.org/10.1021/jf9503927

LEE, S. C. et al. Characterization of new biosurfactant produced by Klebsiella sp. Y6-1 isolated from waste soybean oil. Bioresource Technology, v. 99, n. 7, p. 2288-2292, 2008. PMid:17596933. http:// dx.doi.org/10.1016/j.biortech.2007.05.020

MINEMOTO, Y. et al. Oxidation of linoleic acid encapsulated with gum arabic or maltodextrin by spray-drying. Journal of Microencapsulation, v. 19, n. 2, p. 181-189, 2002. PMid:11837973. http://dx.doi.org/10.1080/02652040110065468

MOORTHY, S. N. Physicochemical and functional properties of tropical tubers starches: a review. Starch/Stärke, v. 54, n. 12, p. 559-592, 2002. http://dx.doi.org/10.1002/1521-379X(200212)54:12<559::AIDSTAR2222559>3.0.CO;2-F

MURÚA-PAGOLA, B.; BERISTAIN-GUEVARA, C. I.; MARTINEZBUSTOS, F. Preparation of starch derivatives using reactive extrusion and evaluation of modified starches as shell materials for encapsulation of flavoring agents by spray drying. Journal of Food Engineering, v. 91, n. 3, p. 380-386, 2009. http://dx.doi. org/10.1016/j.jfoodeng.2008.09.035

OZMEN, L.; LANGRISH, T. A. G. An experimental investigation of the wall deposition of milk powder in a pilot-scale spray dryer. Drying Technology, v. 21, n. 7, p. 1253-1272, 2003. http://dx.doi. org/10.1081/DRT-120023179

PARAMITA, V.; FURUTA, T.; YOSHII, H. High-oil-load encapsulation of medium-chain triglycerides and d-limonene mixture in modified starch by spray drying. Journal of Food Science, v. 77, n. 2, p. 38-44, 2012. PMid:22251159. http://dx.doi.org/10.1111/j.17503841.2011.02534.x

PEREIRA PACHECO, F. E.; MOLINA MEDINA, M. R. Starch extraction from Xanthosoma sagittifolium. Tropical Science, v. 32, n. 2, p. 203-206, 1992.

PITALUA, E. et al. Antioxidative activity of microcapsules with beetroot juice using gum Arabic as wall material. Food and Bioproducts Processing, v. 88, n. 2-3, p. 253-258, 2010. http:// dx.doi.org/10.1016/j.fbp.2010.01.002

PUCHONGKAVARIN, H.; VARAVINIT, S.; BERGTHALLER, W. Comparative study of pilot scale rice starch production by an alkaline and an enzymatic process. Starch/Stärke, v. 57, n. 3-4, p. 134-144, 2005. http://dx.doi.org/10.1002/star.200400279

QI, Z. H.; XU, A. Starch based ingredients for flow encapsulation. Cereal Food World, v. 44, p. 460-465, 1999.

REINECCIUS, G. A. The spray drying of food flavors. Drying Technology, v. 22, n. 6, p. 1289-1324, 2004. http://dx.doi. org/10.1081/DRT-120038731

RISCH, S. J.; REINECCIUS, G. A. Spray-dried orange oil: effect of emulsion size on flavor retention and shelf life. In: RISCH, S. J.; REINECCIUS, G. A. (Ed.). Flavor encapsulation. Washington: American Chemical Society, 1988. p. 67-77. http://dx.doi. org/10.1021/bk-1988-0370.ch008
ROMÁN-GUERRERO, A. et al. Application and evaluation of mesquite gum and its fractions as interfacial film formers and emulsifiers of orange peel-oil. Food Hydrocolloids, v. 23, n. 3, p. 708-713, 2009. http://dx.doi.org/10.1016/j.foodhyd.2008.06.005

SANKARIKUTTY, B. et al. Studies on microencapsulation of cardamom oil by spray drying technique. Journal of Food Science Technology, v. 25, n. 6, p. 352-356, 1988.

SERRIS, G. S.; BILIADERIS, C. G. Degradation kinetics of beetroot pigment encapsulated in polymeric matrices. Journal of the Science of Food and Agriculture, v. 81, n. 8, p. 691-700, 2001. http://dx.doi. org/10.1002/jsfa.864

SHAIKH, J.; BHOSALE, R.; SINGHAL, R. Microencapsulation of black pepper oleoresin. Food Chemistry, v. 94, n. 1, p. 105-110, 2006. http://dx.doi.org/10.1016/j.foodchem.2004.10.056

SHEU, T. Y.; ROSENBERG, M. Microencapsulation by spray drying ethyl caprylate in whey protein and carbohydrate wall systems. Journal of Food Science, v. 60, n. 1, p. 98-103, 1995. http://dx.doi. org/10.1111/j.1365-2621.1995.tb05615.x

SONG, X. et al. Preparation and properties of octenyl succinic anhydride modified early indica rice starch. Starch/Stärke, v. 58, n. 2, p. 109-117, 2006. http://dx.doi.org/10.1002/star.200500444

SOOTTITANTAWAT, A. et al. Microencapsulation by spray drying: influence of emulsion size on the retention of volatile compounds. Journal of Food Science, v. 68, n. 7, p. 2256-2262, 2003. http:// dx.doi.org/10.1111/j.1365-2621.2003.tb05756.x

SOOTTITANTAWAT, A. et al. Effect of water activity on the release characteristics and oxidative stability of d-limonene encapsulated by spray drying. Journal of Agriculture and Food Chemistry, v. 52, n. 5, p. 1269-1276, 2004. PMid:14995132. http://dx.doi. org/10.1021/jf035226a

SOOTTITANTAWAT, A. et al. Influence of emulsion and powder size on the stability of encapsulated d-limonene by spray drying. Innovative Food Science and Emerging Technologies, v. 6, n. 1, p. 107-114, 2005. http://dx.doi.org/10.1016/j.ifset.2004.09.003

SOPADE, P. A.; FILIBUS, T. E. The influence of solid and sugar contents on rheological characteristics of Akamu, a semi-liquid maize food. Journal of Food Engineering, v. 24, n. 2, p. 197-211, 1995. http:// dx.doi.org/10.1016/0260-8774(94)P2643-J

STATSOFT. Statistica. Version 6.0. Tulsa: StatSoft Inc., 2001.

THIES, C. Preparation of microcapsules by using centrifugal force, needles, nozzles and sprays. In: THIES, C. (Ed.). How to make microcapsules: lecture and laboratory manual. St. Louis: Thies Technology, 1995. chap. 3.

TONON, R. V.; FREITAS, S. S.; HUBINGER, M. D. Spray drying of açai juice: effect of inlet temperature and type of carrier agent. Journal of Food Processing and Preservation, v. 35, n. 5, p. 691-700, 2011. http://dx.doi.org/10.1111/j.1745-4549.2011.00518.x

VARAVINIT, S.; CHAOKASEM, N.; SHOBSNGOB, S. Studies of flavor encapsulation by agents produced from modified sago and tapioca starches. Starch/Stärke, v. 53, n. 6, p. 281-287, 2001. http://dx.doi.org/10.1002/1521-379X(200106)53:6<281::AIDSTAR281>3.0.CO;2-R

ZAMBRANO, F; CAMARGO, C. R. O. Optimisation of the conditions for the acid hydrolysis of cassava starch to obtain a fat replacer. Brazilian Journal of Food Technology, v. 4, p. 147-154, 2001. 